\title{
Controlled trial of continuous positive airway pressure given by face mask for hyaline membrane disease
}

\author{
L. P. ALLEN, E. O. R. REYNOLDS, R. P. A. RIVERS, P. N. LE SOUËF, AND \\ P. D. WIMBERLEY
}

From the Departments of Paediatrics and Medical Physics, University College Hospital Medical School, London

SUMMARY A controlled trial of elective intervention with continuous positive airway pressure (CPAP) was performed on 24 infants with hyaline membrane disease whose arterial oxygen tension $\left(\mathrm{PaO}_{2}\right)$ fell below $8 \mathrm{kPa}(60 \mathrm{mmHg})$ while they were breathing a fractional inspired oxygen concentration $\left(\mathrm{F}_{1} \mathrm{O}_{2}\right)$ greater than $0 \cdot 60$. A face mask was used to apply the CPAP. The progress of the 12 infants who were treated on entry to the trial was compared with that of 12 infants who were treated later. All 12 infants in the early-intervention group and 8 infants in the late-intervention group survived. When CPAP was started, $\mathrm{PaO}_{2}$ increased and the early-treated infants breathed high concentrations of oxygen for a shorter period than the late-treated infants. The 4 infants in the earlyintervention group who required mechanical ventilation needed lower mean airway pressures to achieve satisfactory gas exchange than the 7 ventilated infants in the late-intervention group. We conclude that a $\mathrm{PaO}_{2}<8 \mathrm{kPa}$ while breathing an $\mathrm{F}_{\mathrm{r}} \mathrm{O}_{2}>0.60$ is an adequate indication for giving CPAP in hyaline membrane disease, and that early intervention with CPAP allows infants who go on to require mechanical ventilation to be ventilated at lower pressures.

All who have used continuous positive airway pressure (CPAP) for treating hyaline membrane disease agree that it effectively improves arterial oxygen tension $\left(\mathrm{PaO}_{2}\right)$ and reduces the infant's need for a high inspired oxygen concentration $\left(\mathrm{F}_{\mathrm{r}} \mathrm{O}_{2}\right)$ (Gregory et al., 1971 ; Chernick and Vidyasagar, 1972; Bancalari et al., 1973; Chernick, 1973; Fanaroff et al., 1973; Rhodes and Hall, 1973; Baum and Roberton, 1974; Caliumi-Pellegrini et al., 1974; Dunn, 1974; Gerard et al., 1975; Krouscop et al., 1975; Mockrin and Bancalari, 1975; Stahlman and Cotton, 1975; Reynolds, 1975; Roberton, 1976; Durbin et al., 1976). Most authors have inferred that the survival rate of infants with hyaline membrane disease would increase if CPAP was introduced early in the illness, though this has never been clearly shown. CPAP is not without complications (Stahlman and Cotton, 1975; Reynolds, 1975; Roberton, 1976). For example, an incidence of pneumothorax or interstitial emphysema as high as $24 \%$ has been quoted (Chernick, 1973). The correct stage of the illness at which to start treatment, which would be

Received 19 August 1976 at the point when the advantages of treatment would outweight the disadvantages, is therefore unknown. In a previous controlled trial (Durbin et al., 1976), using an endotracheal tube to deliver the CPAP and intervening late in the illness $\left(\mathrm{PaO}_{2}<8 \mathrm{kPa}(60\right.$ $\mathrm{mmHg}$ ) in an $\left.\mathrm{F}_{\mathrm{I}} \mathrm{O}_{2}>0.95\right)$, we found no difference in mortality or morbidity between treated and control groups. We calculated that the maximum increase in survival rate that could be expected in the population of infants with severe hyaline membrane disease admitted to our unit if CPAP were introduced infinitely early was only $5 \%$, but that the percentage of infants who required mechanical ventilation might be reduced from $63 \%$ to $47 \%$.

Having gained experience with a system for administering CPAP via a face mask that seems to be without complications (Allen et al., 1975) we have conducted another controlled trial, intervening earlier $\left(\mathrm{PaO}_{2}<8 \mathrm{kPa}\right.$ in an $\left.\mathrm{F}_{\mathrm{I}} \mathrm{O}_{2}>0.60\right)$. The object was to see if any differences in morbidity or in the progress of the illness could be demonstrated between infants who were treated early and those in another group who were treated later. The results are reported here. 


\section{Patients and methods}

From 1 May 1975 infants with the clinical features of hyaline membrane disease (abnormal retractions of the chest wall, cyanosis, tachypnoea, and grunting) and a chest $x$-ray picture consistent with that diagnosis were eligible for entry to the trial provided they had not previously received any ventilatory assistance other than during resuscitation at birth. The general management of the infants was as described previously (Reynolds, 1975).

Twenty-four infants were randomly entered into an early-intervention group or a late-intervention group if their $\mathrm{PaO}_{2}$ fell $<8 \mathrm{kPa}(60 \mathrm{~mm} \mathrm{Hg})$ while breathing an $\mathrm{F}_{\mathrm{r}} \mathrm{O}_{2}>0 \cdot 60$. Measurements of $\mathrm{PaO}_{2}$ and arterial carbon dioxide tension $\left(\mathrm{PaCO}_{2}\right), \mathrm{pH}$, and base excess (BE) were made in samples of blood obtained through umbilical artery catheters except in four infants, two in each group, in whom sampling was from peripheral arteries, usually the right radial (Shaw, 1968). The analyses were performed immediately using Radiometer or Instrumentation Laboratories equipment present in the unit. Continuously recording umbilical artery catheter-tip electrodes (Conway et al., 1976) were used to monitor the $\mathrm{PaO}_{2}$ of 15 infants and transcutaneous oxygen electrodes (Huch et al., 1974) were used on 12 infants.

In the early-intervention group CPAP, delivered by a face mask, was set up as described by Allen et al. (1975) at a pressure of $0.05 \mathrm{kPa}\left(5 \mathrm{~cm} \mathrm{H}_{2} \mathrm{O}\right)$. $\mathrm{CPAP}$ and $\mathrm{F}_{\mathrm{Y}} \mathrm{O}_{2}$ were then varied to try to maintain the $\mathrm{PaO}_{2}$ as close as possible to $8.65 \mathrm{kPa}(65 \mathrm{mmHg})$. CPAP $>0.07 \mathrm{kPa}\left(7 \mathrm{~cm} \mathrm{H} \mathrm{H}_{2} \mathrm{O}\right)$ and an $\mathrm{F}_{\mathrm{I}} \mathrm{O}_{2}>0.80$ were avoided whenever possible, but both were used if necessary. CPAP $>0 \cdot 1 \mathrm{kPa}\left(10 \mathrm{~cm} \mathrm{H}_{2} \mathrm{O}\right)$ was not allowed.

Infants assigned to the late-intervention group were managed exactly as the early-intervention group except that CPAP was not started when the criteria for entry to the trial were met. If in either group the $\mathrm{PaO}_{2}$ fell $<6.65 \mathrm{kPa}(50 \mathrm{mmHg})$ with the infant breathing an $\mathrm{F}_{1} \mathrm{O}_{2}>0.95$, or if apnoea seemed likely, as judged by the appearance of peripheral vasoconstriction, gasps, or bradycardia (heart rate $<100$ per minute), ventilatory assistance was given in the form of mask-CPAP or mechanical ventilation by face mask or endotracheal tube, depending on the clinical circumstances.

Clinical information, values for arterial blood gas tensions, acid-base data, and CPAP and mechanical ventilator variables were entered as they were obtained into a PDP 11/45 computer via a terminal in the unit and recalled later for analysis. Comparisons between the early-intervention and late-intervention groups were made with Student's paired or unpaired $t$ test or by $\chi^{2}$ using Yates's correction.

\section{Results}

The trial took 12 months to complete. Clinical data and the outcome for the two groups of infants are shown in Table 1. There were no significant differ-

Table 1 Composition of the early-intervention and late-intervention groups of infants. Values given as mean \pm 1 SEM (and range)

\begin{tabular}{|c|c|c|}
\hline & \multicolumn{2}{|l|}{ Group } \\
\hline & $\begin{array}{l}\text { Early-intervention } \\
(n=12)\end{array}$ & $\begin{array}{l}\text { Late-intervention } \\
(n=12)\end{array}$ \\
\hline $\begin{array}{l}\text { No of infants } \\
\text { UCH } \\
\text { Referred } \\
\text { Birthweight (g) } \\
\text { Gestational age (w) } \\
\text { Sex ratio } \\
\text { (boys:girls) } \\
\text { Age at entry to } \\
\text { trial (h) } \\
\text { Survived (no. of } \\
\text { infants) }\end{array}$ & $\begin{array}{l}5 \\
7 \\
1641 \pm 147(1070-2580) \\
32 \cdot 4 \pm 1 \cdot 1(27-36) \\
9: 3 \\
15 \cdot 8 \pm 3 \cdot 0(4-30) \\
12(100 \%)\end{array}$ & $\begin{array}{l}3 \\
9 \\
1545 \pm 149(650-2600) \\
31 \cdot 1 \pm 1 \cdot 0(24-37) \\
11: 1 \\
11 \cdot 9 \pm 3 \cdot 3(4-25)\end{array}$ \\
\hline
\end{tabular}

ences in composition between the groups. Three of the infants in the late-intervention group had abnormalities of coagulation status consistent with liver immaturity and early disseminated intravascular coagulation on their arrival from other hospitals and before entry to the trial. These abnormalities resolved after exchange transfusion. No similar abnormalities were found in the infants in the earlyintervention group.

Effect of CPAP. Table 2 shows values from the infants in the early-intervention group for $\mathrm{F}_{1} \mathrm{O}_{3}$, blood-gas tensions, and acid-base status obtained within 15 minutes before and within 45 minutes after starting CPAP. A significant increase in $\mathrm{PaO}_{2}$ occurred in response to CPAP, but there were no other changes. The mean length of time that CPAP was continued was 46 hours (range 6-107 h). The mean maximum pressure was $0.07 \mathrm{kPa}\left(7 \mathrm{~cm} \mathrm{H}_{2} \mathrm{O}\right)$ (range 0.05-0.09 kPa (5-9 cm $\left.\mathrm{H}_{2} \mathrm{O}\right)$ ). Two infants in the late-intervention group were treated with CPAP delivered by mask because of incipient apnoea as defined above. In neither case was there any increase in $\mathrm{PaO}_{2}$, although breathing appeared to become more regular and their general condition improved. Both went on to require mechanical ventilation two hours later.

Mechanical ventilation. Four infants in the earlyintervention group required mechanical ventilation, 
Table 2 Blood gas and acid-base data from early-intervention and late-intervention groups on entry to trial and after setting up CPAP in the early-intervention group. Values mean \pm 1 SEM except $p H$, where values converted from mean hydrogen-ion concentration in nmol/l, and the range, are given

\begin{tabular}{|c|c|c|c|}
\hline & \multicolumn{3}{|l|}{ Group } \\
\hline & \multicolumn{2}{|l|}{ Early-intervention } & \multirow{2}{*}{$\begin{array}{l}\text { Late-intervention } \\
\text { Entry }(n=12)\end{array}$} \\
\hline & Entry $(n=12)$ & After CPAP $(n=12)$ & \\
\hline $\begin{array}{l}\mathrm{F}_{\mathbf{x}} \mathrm{O}_{2} \\
\mathrm{PaO}_{2}(\mathrm{kPa}) \\
\mathrm{PaCO}_{2}(\mathrm{kPa}) \\
\text { pH } \\
\mathrm{BE}(\mathrm{mmol} / \mathrm{l})\end{array}$ & $\begin{array}{l}0 \cdot 65 \pm 0 \cdot 02 \\
6 \cdot 10 \pm 0 \cdot 25^{*} \\
7 \cdot 62 \pm 0 \cdot 87 \\
7 \cdot 22(7 \cdot 12-7 \cdot 36) \\
-5 \cdot 8 \pm 1 \cdot 2\end{array}$ & $\begin{array}{l}0 \cdot 64 \pm 0.01 \\
11 \cdot 04 \pm 0 \cdot 18 * \\
7 \cdot 62 \pm 0 \cdot 58 \\
7 \cdot 25(7 \cdot 15-7 \cdot 33) \\
-4 \cdot 4 \pm 1 \cdot 3\end{array}$ & $\begin{array}{l}0 \cdot 67 \pm 0 \cdot 02 \\
6 \cdot 35 \pm 0 \cdot 22 \\
8 \cdot 76 \pm 0 \cdot 79 \\
7 \cdot 17(6 \cdot 95-7 \cdot 38) \\
-5 \cdot 5 \pm 1 \cdot 9\end{array}$ \\
\hline
\end{tabular}

$\bullet \mathbf{P}<0.001$.

Conversion: $S I$ to traditional units $-1 \mathrm{kPa} \approx 7.5 \mathrm{mmHg}$.

in two cases because of pneumothorax and in the other two because of incipient apnoea while being treated with CPAP pressures of 0.07 and 0.08 $\mathrm{kPa}\left(7\right.$ and $\left.8 \mathrm{~cm} \mathrm{H}_{2} \mathrm{O}\right)$ respectively and an $\mathrm{F}_{1} \mathrm{O}_{2}$ of $1 \cdot 0$. Seven of the late-intervention group were ventilated, two because they had failed to respond to CPAP and the other five because it was thought safer to ventilate them than to set up CPAP. Three of these five had $\mathrm{PaO}_{2}$ values between 4.00 and 6.65 $\mathrm{kPa}(30$ and $50 \mathrm{mmHg})$ with an $\mathrm{F}_{\mathrm{I}} \mathrm{O}_{2}$ of $1 \cdot 0$, and the other two were ventilated because of incipient apnoea. One infant in each group was successfully managed with mask ventilation. The others were intubated with Warne No. 12 endotracheal tubes.

The ventilators used were Draeger Spiromat 661 or Bourns BP-200 machines. The management of the infants during mechanical ventilation was as previously described (Blake et al., 1973; Reynolds, 1975; Allen et al., 1975; Durbin et al., 1976). For mask ventilation the initial settings were as follows: peak airway pressure $0.12 \mathrm{kPa}\left(12 \mathrm{~cm} \mathrm{H}_{2} \mathrm{O}\right)$, endexpiratory pressure $0.02 \mathrm{kPa}\left(2 \mathrm{~cm} \mathrm{H}_{2} \mathrm{O}\right)$, respiratory frequency 36 cycles per minute, inspiration : expiration ratio $1: 2$ or $1: 1$. When endotracheal tubes were used the settings were: peak airway pressure $0 \cdot 22-0 \cdot 25 \mathrm{kPa}\left(22-25 \mathrm{~cm} \mathrm{H}_{2} \mathrm{O}\right)$, endexpiratory pressure $0.02-0.05 \mathrm{kPa}\left(2-5 \mathrm{~cm} \mathrm{H}_{2} \mathrm{O}\right)$, respiratory frequency $30-40$ cycles per minute, and inspiration : expiration ratio $1: 1$ to $2: 1$. These settings were varied as necessary to give a $\mathrm{PaO}_{2}$ of about $8.6 \mathrm{kPa}(65 \mathrm{mmHg})$ and $\mathrm{a} \mathrm{PaCO}_{2}$ of about $6.6 \mathrm{kPa}(50 \mathrm{mmHg})$.

Satisfactory gas exchange was more difficult to achieve in the late-intervention group. The maximum pressures required are shown in Table 3. Significantly higher mean airway pressures and inspiration : expiration ratios were needed in the late-intervention group. The duration of mechanical ventilation in the survivors was similar in the early-intervention (mean $64 \mathrm{~h}$, range 52-75 h) and late-intervention (mean $66 \mathrm{~h}$, range $35-90 \mathrm{~h}$ ) groups. The infants were weaned from mechanical ventilation via tube-CPAP and mask-CPAP. Intermittent mandatory ventilation was used during weaning in five infants. The total length of time that ventilatory aids (CPAP and mechanical ventilation) were used in the 12 infants in the early-intervention group averaged $83 \mathrm{~h}$ (range 6-183 h) and in the three surviving infants who required ventilatory aids in the lateintervention group $145 \mathrm{~h}$ (range 71-202 h).

Table 3 V'alues (mean $\pm 1 S E M$ ) for mechanical ventilator variables when mean airway pressure was highest in the early-intervention and late-intervention groups. These values were obtained 2-4 hours after starting ventilation. PaO 2 was between 6.30 and $8.60 \mathrm{kPa}\left(47\right.$ and $67 \mathrm{~mm} \mathrm{Hg}$ ), $\mathrm{PaCO}_{2}$ between 4.52 and $9.17 \mathrm{kPa}(34$ and $69 \mathrm{~mm} \mathrm{Hg}$ ), and pH between $7 \cdot 19$ and $7 \cdot 41$

\begin{tabular}{|c|c|c|c|}
\hline & \multicolumn{2}{|l|}{ Group } & \multirow[b]{2}{*}{$P$} \\
\hline & $\begin{array}{l}\text { Early intervention } \\
(n=4)\end{array}$ & $\begin{array}{l}\text { Late-intervention } \\
(n=7)\end{array}$ & \\
\hline $\begin{array}{l}\mathrm{F}_{\mathrm{x}} \mathrm{O}_{2} \\
\mathrm{Respiratory} \text { frequency }(\mathrm{cycles} / \mathrm{min}) \\
\text { Peak airway pressure }(\mathrm{kPa}) \\
\text { End-expiratory pressure }(\mathrm{kPa}) \\
\text { Inspiration:expiration ratio } \\
\text { Mean airway pressure }(\mathrm{kPa})\end{array}$ & $\begin{array}{l}0 \cdot 85 \pm 0.03 \\
33 \cdot 8 \pm 3 \cdot 7 \\
0 \cdot 20 \pm 0 \cdot 03 \\
0 \cdot 03 \pm 0 \cdot 01 \\
0 \cdot 62 \pm 0 \cdot 12: 1 \\
0 \cdot 09 \pm 0.01\end{array}$ & $\begin{array}{l}0 \cdot 89 \pm 0.02 \\
35 \cdot 4 \pm 1 \cdot 6 \\
0 \cdot 26 \pm 0.03 \\
0 \cdot 03 \pm 0 \cdot 01 \\
1 \cdot 79 \pm 0 \cdot 26: 1 \\
0 \cdot 18 \pm 0.03\end{array}$ & $\begin{array}{l}\text { NS } \\
\text { NS } \\
\text { NS } \\
\text { NS } \\
<0.02 \\
<0.05\end{array}$ \\
\hline
\end{tabular}

Conversion: SI to traditional units-1 $\mathrm{kPa} \approx 7.5 \mathrm{mmHg}$ and $100 \mathrm{~mm} \mathrm{H}_{2} \mathrm{O}$. 
Oxygen therapy. Table 3 shows that the infants in the early-intervention group breathed high concentrations of oxygen for a shorter period than those in the late-intervention group. The surviving infants had, however, recovered sufficiently to be breathing room air spontaneously at the same age (Table 4).

Complications of therapy and cause of death. Two infants in the early-intervention group developed pneumothoraces while being treated with $0.05 \mathrm{kPa}$ $\left(5 \mathrm{~cm} \mathrm{H} \mathrm{H}_{2} \mathrm{O}\right.$ ) of CPAP. Both recovered. One infant in the late-intervention group died after developing a pneumothorax while being mechanically ventilated. The age at death of the four infants, all in the late-intervention group, who died during treatment of their hyaline membrane disease was 24-37 hours. They were born at 24-33 weeks of gestation, weighing $650-1584 \mathrm{~g}$. All had severe changes of hyaline membrane disease and intraventricular haemorrhages at necropsy. Two other infants, one in each group, died later of causes apparently unrelated to their hyaline membrane disease. One collapsed aged 22 days with a falling neutrophil count and evidence of disseminated intravascular coagulation. An infective cause was presumed but cultures were negative and at necropsy nothing other than the effects of disseminated intravascular coagulation was found. The other infant developed fulminating necrotizing enterocolitis when aged one month. The surviving infants are progressing normally at follow-up.

\section{Discussion}

Survival. This is the sixth controlled trial in which infants with hyaline membrane disease have been treated with CPAP or continuous negative pressure (CNP) if they needed an $\mathrm{F}_{\mathrm{r}} \mathrm{O}_{2}$ greater than $0.4-0.7$ to maintain $\mathrm{a} \mathrm{PaO}_{2}$ of $5 \cdot 32-7 \cdot 98 \mathrm{kPa}(40-60 \mathrm{mmHg})$ (Fanaroff et al., 1973; Rhodes and Hall, 1973; Gerard et al., 1975; Krouskop et al., 1975; Mockrin and Bancalari, 1975). Rhodes and Hall (1973) showed an improvement in survival over infants in whom intervention was at a later stage of their illness, but only among those infants who weighed $>1500 \mathrm{~g}$ at birth $(\mathrm{P}<0 \cdot 05)$. None of the other trials have shown any increase in survival associated with early intervention. In our study there was, however, a trend in that direction (Table 1). This might partly have been because the late-intervention group contained the smallest infant in either group and also 3 infants with coagulation problems.

The numbers in all the trials so far have been small and the survival rates were high whether or not CPAP was used early in the illness, so it is not surprising that statistical differences have not been found. Very much larger numbers would be required. Taking the results of all the trials-which are very similar in design - together, 67 infants in the early-intervention groups have survived and 14 have died, as against 58 survivors and 25 deaths in the late-intervention groups. This difference is significant $\left(\chi^{2}-5 \cdot 94, \mathrm{P}<0 \cdot 02\right)$. It seems likely, therefore, that early intervention with CPAP reduces mortality from hyaline membrane disease.

Since all our infants in the early-intervention group recovered from their hyaline membrane disease and the four that needed mechanical ventilation were easy to ventilate (Table 3 ), we see little point in intervening earlier still unless the infant is also suffering from apnoeic attacks due to immature control of breathing, for which CPAP has been found to be useful treatment (Kattwinkel et al., 1975).

Oxygen therapy and mechanical ventilation. The initiation of CPAP in our patients was followed by an increase in $\mathrm{PaO}_{2}$ (Table 2) and the infants breathed high concentrations of oxygen for a shorter period than those treated later (Table 4). These results are similar to those previously reported (Gregory et al., 1971; Chernick and Vidyasagar, 1972; Bancalari et al., 1973; Fanaroff et al., 1973; Rhodes and Hall, 1973; Baum and Roberton, 1974; Caliumi-Pellegrini et al., 1974; Allen et al., 1975; Gerard et al., 1975; Krouskop et al., 1975; Mockrin and Bancalari, 1975). The survivors in the late-intervention

Table 4 Oxygen therapy in the surviving infants in the early-intervention and late-intervention groups (values mean \pm 1 SEM)

\begin{tabular}{llll}
\hline & Group & \\
\cline { 2 - 4 } & $\begin{array}{l}\text { Early-intervention } \\
(n=12)\end{array}$ & $\begin{array}{l}\text { Late-intervention } \\
(n=8)\end{array}$ \\
\hline $\begin{array}{l}\mathrm{F}_{\mathrm{x}} \mathrm{O}_{2} \\
>0 \cdot 8(\mathrm{~h})\end{array}$ & $17 \cdot 9 \pm 6 \cdot 9$ & & \\
$>0 \cdot 5(\mathrm{~h})$ & $51 \cdot 7 \pm 10 \cdot 7$ & $50 \cdot 7 \pm 11 \cdot 5$ & $103 \cdot 3 \pm 22 \cdot 0$ \\
$\begin{array}{c}\text { Age when survivors were breathing } \\
\text { room air spontaneously (days) }\end{array}$ & $9 \cdot 4 \pm 1 \cdot 3$ & $11 \cdot 1 \pm 2 \cdot 0$ & $<0 \cdot 02$ \\
\hline
\end{tabular}


group, however, were breathing air spontaneously at the same age as the infants in the early-intervention group, so the lungs of the infants in the lateintervention group were most unlikely to have been harmed in any important way by breathing high concentrations of oxygen. A reason often cited for early intervention with CPAP is that it reduces the risk of bronchopulmonary dysplasia, which some authors have thought was caused by oxygen breathing (Northway et al., 1967; Banerjee et al., 1972). But bronchopulmonary dysplasia has never been described in spontaneously breathing infants with hyaline membrane disease however much oxygen they have breathed, and evidence has been presented (Reynolds and Taghizadeh, 1974; Taghizadeh and Reynolds, 1976) that although this condition is probably multifactorial in origin the main cause is mechanical trauma to the lung due to the use of very high peak airway pressures and respiratory frequencies during mechanical ventilation. Our results reinforce our view (Reynolds, 1975) that CPAP should not be started solely to keep the $\mathrm{F}_{\mathrm{r}} \mathrm{O}_{2}$ below some arbitrary level in order to avoid the possible hazards of pulmonary oxygen toxicity.

Our most interesting finding was that higher inspiration : expiration ratios and mean airway pressures were required to achive satisfactory gas exchange in the mechanically ventilated infants in the late-intervention group (Table 3). Two infants needed peak airway pressures of $0.34 \mathrm{kPa}(34 \mathrm{~cm}$ $\mathrm{H}_{2} \mathrm{O}$ ), end expiratory pressures of $0.08 \mathrm{kPa}(8 \mathrm{~cm}$ $\mathrm{H}_{2} \mathrm{O}$ ), and inspiration: expiration ratios of $3: 1$ at a respiratory frequency of 32 cycles per minute and an $\mathrm{F}_{1} \mathrm{O}_{2}$ of $1 \cdot 0$. After $\frac{1}{2}$ to 2 hours the $\mathrm{PaO}_{2}$ as shown by catheter-tip electrodes (Conway et al., 1976) increased from $5 \cdot 32-6 \cdot 65 \mathrm{kPa}(40-50 \mathrm{mmHg})$ to $>13.3 \mathrm{kPa}(100 \mathrm{mmHg})$ and radiography showed well-inflated lungs. The high airway pressures could then rapidly be reduced, as described before (Reynolds, 1974; Conway et al., 1976). The reason that higher pressures were needed in the late-intervention group may be that the lung had collapsed further than in the early-intervention group, and that it was difficult to overcome the resistance offered by surfactant-deficient air-liquid interfaces with small radii of curvature at the entrance to collapsed alveoli (Taghizadeh and Reynolds, 1976). A further reaon may have been that surfactant was better conserved in the early-intervention group (Wyszogrodski et al., 1975). A benefit of early intervention with CPAP (or CNP) may be that the dangers associated with the use of high airway pressures during subsequent mechanical ventilation-such as pneumothorax, obstruction of the pulmonary circulation, and bronchopulmonary dysplasiacan be avoided.
We thank the medical and nursing staff of the Neonatal Unit, J. C. Clifton, D. Ingram, H. Jolly, Miss H. Roth, Dr L. P. Soutter, and Dr A. Taghizadeh for their help.

\section{References}

Allen, L. P., Blake, A. M., Durbin, G. M., Ingram, D., Reynolds, E. O. R., and Wimberley, P. O. (1975). Continuous positive airway pressure and mechanical ventilation by face-mask in newborn infants. British Medical Journal, 4, 137-139.

Bancalari, E., Garcia, O. L., and Jesse, M. J. (1973). Effects of continuous negative pressure on lung mechanics in idiopathic respiratory distress syndrome. Pediatrics, 51, 485-493.

Banerjee, C. K., Girling, D. J., and Wigglesworth, J. S. (1972). Pulmonary fibroplasia in newborn babies treated with oxygen and artificial ventilation. Archives of Disease in Childhood, 47, 509-518.

Baum, J. D., and Roberton, N. R. C. (1974). Distending pressure in infants with respiratory distress syndrome. Archives of Disease in Childhood, 49, 771-781.

Blake, A. M., Collins, L. M., Durbin, G. M., Hunter, N. J., Macnab, A. J., Reynolds, E. O. R., and Sellers, G. (1973). Simplified mechanical ventilation for hyaline-membrane disease. Lancet, 2, 1176-1178.

Caliumi-Pellegrini, G., Agostoni, R., Orzalesi, M., Nodari, S., Marzetti, G., Savignoni, P. G., and Bucci, G. (1974). Twin nasal cannula for administration of continuous positive airway pressure to newborn infants. Archives of Disease in Childhood, 49, 228-230.

Chernick, V. (1973). Hyaline-membrane-disease-therapy with constant lung-distending pressure. New England Journal of Medicine, 289, 302-304.

Chernick, V., and Vidyasagar, D. (1972). Continuous negative chest wall pressure in hyaline membrane disease; one year experience. Pediatrics, 49, 753-760.

Conway, M., Durbin, G. M., Ingram D., McIntosh, N., Parker, D., Reynolds, E. O. R., and Soutter, L. (1976). Continuous monitoring of arterial oxygen tension using a catheter-tip polarographic electrode in infants. Pediatrics, 57, 244-250.

Dunn, P. M. (1974). Continuous positive airway pressure using the Gregory box. Procedings of the Royal Society of Medicine, 67, 245-247.

Durbin, G. M., Hunter, N. J., McIntosh, N., Reynolds, E. O. R., and Wimberley, P. D. (1976). Controlled trial of continuous inflating pressure for hyaline membrane disease. Archives of Disease in Childhood, 51, 163-169.

Fanaroff, A. A., Cha, C. C., Sosa, R., Crumrine, R. S., and Klaus, M. H. (1973). Controlled trial of continuous negative external pressure in the treatment of severe respiratory distress syndrome. Journal of Pediatrics, 82, 921-928.

Gerard, P., Fox, W. W., Outerbridge, E. W., Beaudry, P. H., and Stern, L. (1975). Early versus late introduction of continuous negative pressure in the management of the idiopathic respiratory distress syndrome. Journal of Pediatrics, 87, 591-595.

Gregory, G. A., Kitterman, J. A., Phibbs, R. H., Tooley, W. H., and Hamilton, W. K. (1971). Treatment of the idiopathic respiratory-distress syndrome of the newborn with continuous positive airway pressure. New England Journal of Medicine, 284, 1333-1340.

Huch, R., Lübbers, D. W., and Huch, A. (1974). Reliability of transcutaneous monitoring of arterial $\mathbf{P O}_{2}$ in newborn infants. Archives of Disease in Childhood, 49, 213-218. 
Kattwinkel, J., Nearman, H. S., Fanaroff, A. A., Katona, P. G., and Klaus, M. H. (1975). Apnea of prematurity. Comparative therapeutic effects of cutaneous stimulation and nasal continuous positive airway pressure. Journal of Pediatrics, 86, 588-592.

Krouskop, R. W., Brown, E. G., and Sweet, A. Y. (1975). The early use of continuous positive airway pressure in the treatment of idiopathic respiratory distress syndrome. Journal of Pediatrics, 87, 263-267.

Mockrin, L. D., and Bancalari, E. H. (1975). Early versus delayed initiation of continuous negative pressure in infants with hyaline membrane disease. Journal of Pediatrics, 87, 596-601.

Northway, W. H., Rosan, R. C., and Porter, D. Y. (1967). Pulmonary disease following respirator therapy of hyaline membrane disease: broncho-pulmonary dysplasia. New England Journal of Medicine, 276, 357-368.

Reynolds, E. O. R. (1974). Pressure waveform and ventilator settings for mechanical ventilation in severe hyaline membrane disease. International Anesthesiology Clinics, 12, 259-280.

Reynolds, E. O. R. (1975). Management of hyaline membrane disease. British Medical Bulletin, 31, 18-24.

Reynolds, E. O. R., and Taghizadeh, A. (1974). Improved prognosis of infants mechanically ventilated for hyaline membrane disease. Archives of Disease in Childhood, 49, 505-515.
Rhodes, P. G., and Hall, R. T. (1973). Continuous positive airway pressure delivered by face-mask in infants with the idiopathic respiratory distress syndrome. Pediatrics, 52, 1-5.

Roberton, N. R. C. (1976). CPAP or not CPAP? Archives of Disease in Childhood, 51, 161-162.

Shaw, J. C. L. (1968). Arterial sampling from the radial artery in premature and full-term infants. Lancet, 2, 389390.

Stahlman, M. T., and Cotton, R. B. (1975). Commentary. Journal of Pediatrics, 87, 601.

Taghizadeh, A., and Reynolds, E. O. R. (1976). Pathogenesis of bronchopulmonary dysplasia following hyaline membrane disease. American Journal of Pathology, 82, 241-258.

Wyszogrodski, I., Kyei-Aboagye, K., Taeusch, H. W., and Avery, M. E. (1975). Surfactant inactivation by hyperventilation; conservation by end-expiratory pressure. Journal of Applied Physiology, 38, 461-466.

Correspondence to Professor E. O. R. Reynolds, Department of Paediatrics, University College Hospital Medical School, Huntley Street, London WC1E 6DH. 
so as to completely replace the chicken feeds. Sucrose is added to the diet (e.g. as fruit puree) before discharge. If lactose is tolerated then invariably sucrose will also be tolerated, since secondary lactose intolerance usually persists for longer periods of time than secondary sucrose intolerance.

Day 10. The patient is discharged home on a glutenfree diet and closely followed-up in the outpatient department.

If there is a family history of coeliac disease or if onset of symptoms followed the introduction of gluten-containing foods into the infant's diet, then it is our policy to perform a small intestinal biopsy before and after a gluten challenge 1 to 2 years later (Packer et al., 1974). If there is clinical or biochemical evidence of deterioration on a gluten-free diet, a small intestinal biopsy is performed to exclude an enteropathy caused by cows' milk protein, before returning the patient to a cows' milk proteinfree diet. If the patient thrives and does not fulfil the diagnostic criteria for gluten challenge as outlined above, gluten is introduced to the diet after approximately 3 to 6 months, and the patient is followed up at regular intervals for 2 years. If during this time there is any clinical or biochemical evidence of coeliac disease a small intestinal biopsy is performed.

\section{Erratum}

In the article on 'Controlled trial of continuous positive airway pressure given by face mask for hyaline membrane disease' by Allen et al., May 1977, pp. 373-378, the published values for CPAP and ventilation therapy on pages 374, 375, 376, 377, and in Table 3 (corrected version published below) were incorrect from the decimal point being sited one place to the left, resulting in the figures given being 10 times too small.

Table 3 Values (mean \pm 1 SEM) for mechanical ventilator variables when mean airway pressure was highest in the early-intervention and late-intervention groups. These values were obtained 2-4 hours after starting ventilation. PaO 2 was between $6 \cdot 30$ and $8.60 \mathrm{kPa}(47$ and $67 \mathrm{~mm} \mathrm{Hg}), \mathrm{PaCO}_{2}$ between 4.52 and $9 \cdot 17 \mathrm{kPa}(34$ and $69 \mathrm{mmHg})$, and pH between $7 \cdot 19$ and $7 \cdot 41$

\begin{tabular}{|c|c|c|c|}
\hline & \multicolumn{2}{|l|}{ Group } & \multirow[b]{2}{*}{$\boldsymbol{P}$} \\
\hline & $\begin{array}{l}\text { Early intervention } \\
(n=4)\end{array}$ & $\begin{array}{l}\text { Late intervention } \\
(n=7)\end{array}$ & \\
\hline $\begin{array}{l}\mathrm{FrO}_{2} \\
\text { Respiratory frequency (cycles/min) } \\
\text { Peak airway pressure (kPa) } \\
\text { End-expiratory pressure (kPa) } \\
\text { Inspiration : expiration ratio } \\
\text { Mean airway pressure (kPa) }\end{array}$ & $\begin{array}{l}0 \cdot 85 \pm 0 \cdot 03 \\
33 \cdot 8 \pm 3 \cdot 7 \\
2 \cdot 0 \pm 0 \cdot 28 \\
0 \cdot 3 \pm 0 \cdot 11 \\
0 \cdot 62 \pm 0 \cdot 12: 1 \\
0 \cdot 91 \pm 0 \cdot 08\end{array}$ & $\begin{array}{l}0 \cdot 89 \pm 0 \cdot 02 \\
35 \cdot 4 \pm 1 \cdot 6 \\
2 \cdot 6 \pm 0 \cdot 27 \\
0 \cdot 27 \pm 0 \cdot 11 \\
1 \cdot 79 \pm 0 \cdot 26: 1 \\
1 \cdot 76 \pm 0 \cdot 25\end{array}$ & $\begin{array}{l}\text { NS } \\
\text { NS } \\
\text { NS } \\
\text { NS } \\
<0.02 \\
<0.05\end{array}$ \\
\hline
\end{tabular}

Conversion: $S I$ to traditional units $-1 \mathrm{kPa} \approx 7.5 \mathrm{mmHg}$ and $100 \mathrm{~mm} \mathrm{H}_{2} \mathrm{O}$. 